\title{
ATYPICAL MRI FINDINGS IN CEREBRAL ADRENOLEUKODYSTROPHY: A CASE REPORT
}

\author{
Koray Koç ${ }^{1}$, Arzu Canan ${ }^{2}$ Pınar Koç ${ }^{3}$, Kamil Karaali ${ }^{4}$, Özgür Duman ${ }^{5}$ and Utku Şenol ${ }^{4}$ \\ ${ }^{1}$ Antalya Ataturk State Hospital, Department of Radiology, Antalya, Turkey; \\ ${ }^{2}$ University of Texas Southwestern Medical Center at Dallas, Department of Radiology, Dallas, Texas, USA; \\ ${ }^{3}$ Antalya Ataturk Training and Research Hospital, Department of Radiology, Antalya, Turkey; \\ ${ }^{4}$ Akdeniz University, Faculty of Medicine, Department of Radiology, Antalya, Turkey; \\ ${ }^{5}$ Akdeniz University, Faculty of Medicine, Department of Child Neurology, Antalya, Turkey
}

SUMMARY - Adrenoleukodystrophy is a rare X-linked hereditary disease that results in accumulation of very-long-chain fatty acids in all body tissues, thus causing demyelination of the white matter. Magnetic resonance imaging (MRI) is a reliable radiological modality to demonstrate the extension of brain lesions and severity of the disease. In the classic form, the parieto-occipital white matter is affected. Besides, atypical MRI findings such as primary frontal lobe involvement are rarely described. We report a case of adrenoleukodystrophy presenting with rare MRI findings such as bilateral symmetric frontal lobe white matter changes suggesting anterior predominance.

Key words: Adrenoleukodystrophy; Magnetic resonance imaging; Very-long-chain fatty acids; White matter

\section{Introduction}

Adrenoleukodystrophy, a hereditary metabolic disease, is caused by mutation on the ABCD1 gene on $\mathrm{Xq} 28$ and results in defect of peroxisomal beta-oxidation and accumulation of the very-long-chain fatty acids (VLCFA) in all body tissues. The incidence of adrenoleukodystrophy shows male predominance and affects approximately 1:20,000 males ${ }^{1}$.

Magnetic resonance imaging (MRI) can demonstrate brain involvement and extension of the lesions ${ }^{2}$. Computed tomography can detect some changes but MRI is more sensitive and correlates well with histologic findings ${ }^{3}$.

We report a case of adrenoleukodystrophy presenting with rare MRI findings such as bilateral symmetric frontal lobe white matter changes.

Correspondence to: Koray Koç, MD, Antalya Ataturk State Hospital, Department of Radiology, Antalya, Turkey

E-mail: koraykoc@yahoo.com

Received April 12, 2016, accepted August 22, 2016

\section{Case Report}

A 10-year-old boy was referred to Department of Child Neurology, Antalya Ataturk State Hospital, with complaint of progressive loss of motor and speech skills. He was born without complications after fullterm, uneventful pregnancy. There was no record of his Apgar score, however, according to his parents, there was no prenatal or postnatal problem. He acquired his motor milestones and speech at appropriate age. His family history was unremarkable. He complained of progressive weakness of legs, walking difficulty, and slurred speech for eighteen months.

On physical examination, the patient had appropriate weight and height, and showed normal cooperation. He could not walk alone and talk but he gazed with eyes and obeyed simple commands. Muscle tone was moderately increased in lower limbs. Deep tendon reflexes were brisk with ankle clonus and bilateral extensor plantar response. No other abnormalities were noted.

Results of routine blood count, serum electrolytes, sugar, calcium, urea, creatinine, liver function tests, ce- 


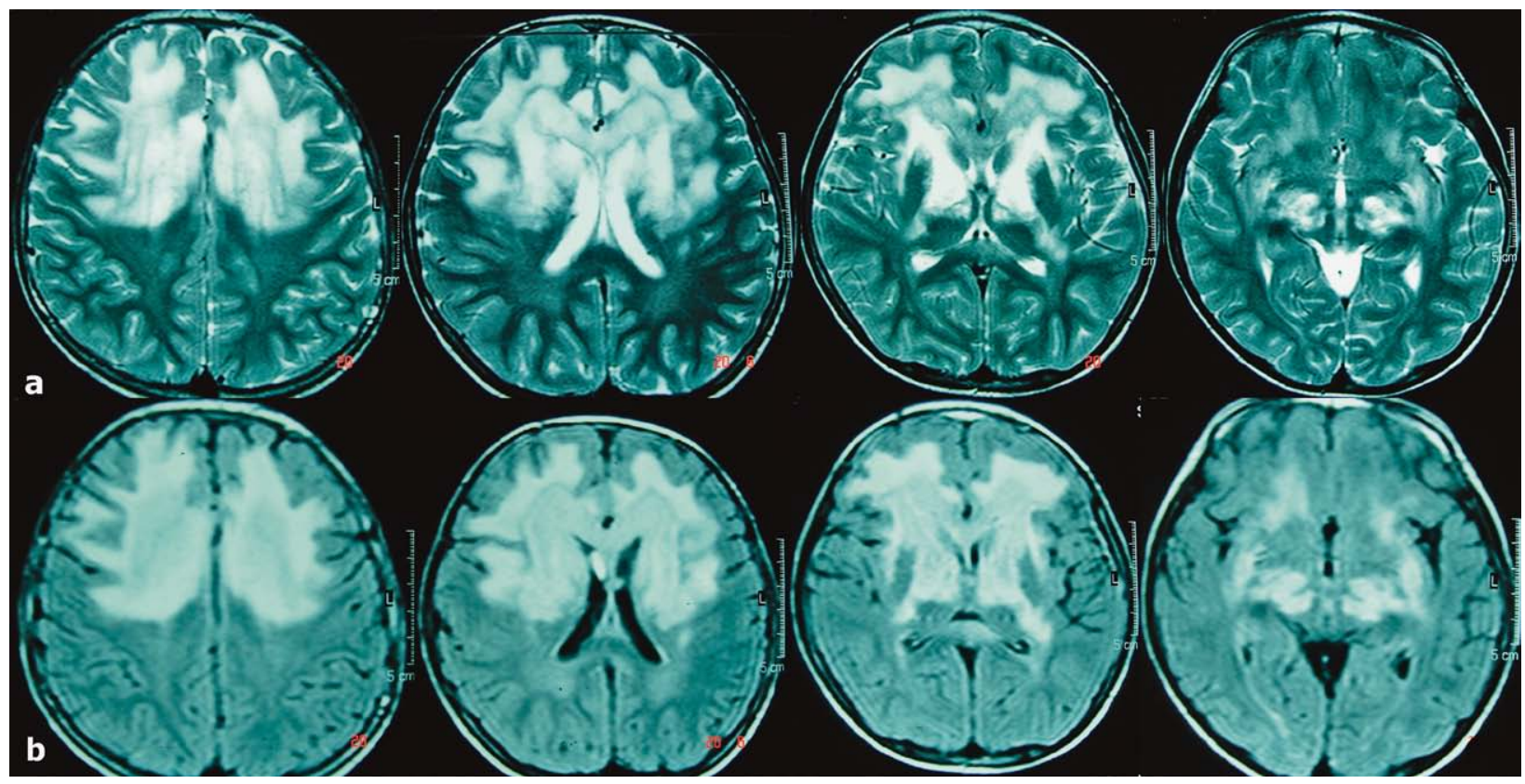

Fig. 1. Consecutive T2-weighted (a) and fluid-attenuated inversion recovery (FLAIR) weighted (b) transverse images demonstrated multiple signal changes on the frontal white matter, genu of corpus callosum, bilateral internal-external capsules and thalamus suggesting bilateral frontal involvement.

rebrospinal fluid and urine analysis were normal. MRI revealed symmetric increased signal intensities in the bilateral frontal periventricular and subcortical white matter with contrast enhancement. There were no mass effects on the adjacent structures. The lesion extended through the genu and splenium of the corpus callosum, bilateral internal and external capsules, visual and auditory pathways, and reached both anterior parts of the thalamus (Fig. 1a and b). The cerebellar white matter, anterior parts of the mesencephalon and pons were also involved (Loes score, 17). MR spectroscopy demonstrated mildly increased choline level while $\mathrm{N}$-acetyl-aspartate level was decreased. The patient's medical history and radiologic findings suggested a metabolic disorder. The diagnosis of adrenoleukodystrophy was confirmed by fatty acid analysis of blood plasma, which showed an abnormal VLCFA level. Testing showed an elevated concentration of hexacosanoate (C26:0), and the $\mathrm{C} 24 / \mathrm{C} 22$ and $\mathrm{C} 26 / \mathrm{C} 22$ ratios also were abnormally high.

\section{Discussion}

Classic presentation of the disease is connected with distribution of the cerebral white matter demye- lination. Classically, demyelination due to the accumulation of VLCFA begins bilaterally in the occipital region and spreads to the splenium, cerebral white matter and cerebellum. Frontal white matter is affected in the last stage of the disease ${ }^{1,2}$. Contrary, in our case, MRI revealed bilateral frontal white matter demyelination without occipital involvement and rostrocaudal progression. This very rare pattern has been documented rarely in the English literature ${ }^{3-5}$.

Measurement of plasma VLCFA levels is the most commonly used and reliable diagnostic test. Elevation of C26:0 and C26:1 levels and high C24/C22 and C26/ $\mathrm{C} 22$ ratios are indicative of adrenoleukodystrophy ${ }^{6}$.

Brain MRI is a reliable radiological modality to demonstrate distribution of demyelination and determine the severity of the disease ${ }^{2}$. Three classic patterns of brain MRI based on anatomic location of the lesions were described by Loes et al. ${ }^{7}$ in 1994. Recently, Loes et al. ${ }^{8}$ have modified them and established five distinct patterns according to anatomic location of the initial T2 signal hyperintensity, as follows: 1) parietooccipital lobes and splenium of the corpus callosum (66\%, seen mainly in children); 2) frontal lobe or genu of the corpus callosum (15.5\%, seen mainly in adolescents); 3 ) frontopontine or corticospinal tracts $(12 \%$, 
seen mainly in adults); 4) cerebellar white matter involvement (1\%, seen mainly in adolescents); and 5) combined involvement of the parieto-occipital and frontal white matter (2.5\%, seen mainly in children). Our patient had primary involvement of frontal lobes and genu of the corpus callosum, described as pattern 2. According to Loes et al. ${ }^{8}$, pattern 2 is mainly seen in adolescents, however, our patient was a 10 -year-old boy. In our patient, Loes score was indicative of severe cerebral involvement in active state. Recently, other radiological modalities such as proton MR spectroscopy, diffusion tensor imaging, and magnetization transfer imaging are under investigation to provide additional information ${ }^{9,10}$.

In conclusion, clinical presentation and distribution of the lesions range widely. MRI findings in adrenoleukodystrophy correlate with disease progression, severity and outcomes. This indicates the need for radiologists to be aware of the diagnosis of adrenoleukodystrophy, especially in a child with neurological disorders and white matter signal changes on MRI.

\section{References}

1. Moser HW, Mahmood A, Raymond GV.X-linked adrenoleukodystrophy. Nat Clin Pract Neurol. 2007;3:140-51. https:// doi.org/10.1038/ncpneuro0421

2. Kim JH, Kim HJ. Childhood X-linked adrenoleukodystrophy: clinical-pathologic overview and MR imaging manifestations at initial evaluation and follow-up. RadioGraphics. 2005;25: 619-31. https://doi.org/10.1148/rg.253045118

3. Mac Donald JT, Stauffer AE, Heitoff K. Adrenoleukodystrophy: early frontal lobe involvement on computed tomography (case report). J Comput Assist Tomogr. 1984;8:128-30.

4. Castellote A, Vera J, Vazquez E, et al. MR in adrenoleukodystrophy: atypical presentation as bilateral frontal demyelination AJNR Am J Neuroradiol. 1995;16:814-5.

5. Nowak J, Löbel U, Wölf M, et al. MRI demyelination pattern and clinical course in a child with cerebral X-linked adrenoleukodystrophy (X-ALD). Acta Radiol Open. 2015;4:204. https:// doi.org/10.1177/2047981615573655

6. Moser AB, Kreiter N, Bezman L, et al. Plasma very long chain fatty acids in 3,000 peroxisome disease patients and 29,000 controls. Ann Neurol. 1999;45:100-10. https://doi.org/10.1002 /1531-8249(199901)45:1<100::AID-ART16>3.0.CO;2-U

7. Loes DJ, Hite S, Moser H, et al. Adrenoleukodystrophy: a scoring method for brain MR observations. AJNR Am J Neuroradiol. 1994;15:1761-6.

8. Loes DJ, Fatemi A, Melhem ER, et al. Analysis of MRI patterns aids prediction of progression in X-linked adrenoleukodystrophy. Neurology. 2003;61:369-74. https://doi.org/10.1212 /01.WNL.0000079050.91337.83

9. Eichler FS, Itoh R, Barker PB, et al. Proton MR spectroscopic and diffusion tensor brain MR imaging in X-linked adrenoleukodystrophy: initial experience. Radiology. 2002;225:245-52. https://doi.org/10.1148/radiol.2251011040

10. Fatemi A, Smith SA, Dubey P, et al. Magnetization transfer MRI demonstrates spinal cord abnormalities in adrenomyeloneuropathy. Neurology. 2005;64:1739-45. https://doi.org/ 10.1212/01.WNL.0000164458.02141.06

Sažetak

\title{
NETIPIČNI NALAZI MAGNETSKE REZONANCIJE U CEREBRALNOJ ADRENOLEUKODISTROFIJI: PRIKAZ SLUČAJA
}

\author{
K. Koş, A. Canan, P. Koş, K. Karaali, Ö. Duman i U. Şenol
}

Adrenoleukodistrofija je rijetka $\mathrm{X}$-vezana nasljedna bolest nakupljanja masnih kiselina dugog lanca u svim tjelesnim tkivima, što uzrokuje demijelinizaciju bijele tvari. Magnetska rezonancija (MR) je pouzdana radiološka metoda kojom se dokazuju razmjeri oštećenja mozga i težina bolesti. U klasičnom obliku bolesti zahvaćena je parieto-okcipitalna bijela tvar. Uz to, rijetko se opisuju netipični nalazi MR kao što je primarna zahvaćenost frontalnog režnja. Opisujemo slučaj adrenoleukodistrofije koja se prikazala rijetkim nalazima MR, tj. obostranim simetričnim promjenama bijele tvari u frontalnom režnju, ukazujući na prevladavajuću zahvaćenost prednjih dijelova.

Key words: Adrenoleukodistrofija; Magnetska rezonancija; Masne kiseline vrlo dugog lanca; Bijela tvar 